\title{
IMMIGRANTS FROM THE POLISH-LITHUANIAN COMMONWEALTH IN THE EARLY STAGES OF EUROPEAN COLONIZATION OF THE CAPE COLONY (1652-1707)
}

\author{
Mariusz Kowalski \\ Institute of Geography and Spatial Organization \\ Polish Academy of Sciences \\ Twarda 51/55, 00-818 Warsaw: Poland \\ e-mail address: mar.kow@twarda.pan.pl
}

\begin{abstract}
While the Commonwealth of Two Nations (Polish-Lithuanian Commonwealth, 1569-1795) did not have colonies of its own, emigrants from its territory did play a part in the colonial enterprise, i.a. the Dutch engagement in South Africa. The group of persons involved was small, but then so were the overall number of settlers and soldiers from all countries combined, ensuring that the Polish influence is not be ignored. Poles (mainly Polish Prussians) in South Africa played their part in the emergence of a new society, as well as in the process whereby the country came to be known and brought under management. They were also co-organizers of pioneering expeditions inland, as well as participating in the first armed encounters with Bantu (Xhosa) people.
\end{abstract}

\section{Key words}

historical migrations - immigrants - Dutch colonization - Polish-Lithuanian Commonwealth

- South Africa - Cape Colony • Poles

\section{Introduction}

The presence of Poles at the outset of South Africa's colonization would seem to be a matter of some interest, if thus far a phenomenon only poorly known. The few references that do exist are usually used solely to introduce presentations on the fates of South Africa's later Polonia. This means that there remains a shortage of work on the part played by Poles in the reconnoitring and later management of a land previously unknown to Europeans, as well as in the laying of the foundations for a new society of European origin.

The pioneer of Polish research into South African Polonia is Arkadiusz Żukowski, whose find- ings are to be found in many articles published in Poland and South Africa alike (Żukowski 1994a, 2001, 2005), as well as in two Polish-published books (Żukowski 1994b, 2008). That author mentions several individuals from Poland appearing in the Cape Colony in the initial period of Dutch colonization, i.e. Paweł Petkow, Jan Liske, Piotr Mow, Piotr Hansz and Jan Cijeppel (the latter probably the same as Jan Knuppel). In discussing the final phase of Dutch rule, the author also mentions Ignacy Werredilski, Jan Sowiecki and Krystian Troske (founder of the Troskie family). The Polish ancestors of today's Afrikaner families also include Jan Kitschuck (founder of the Kitshoff family), Jan Latski (founder of the 
Latsky family), Antoni Sevascowitz and Mateusz Abagostus (Żukowski 1994b). However, these individuals only settled at the Cape Colony in the 19th century.

The studies elaborated of Mariusz Kowalski (2005, 2006a, 2006b, 2009) have stressed the Polish origins of around 20 of today's South African (mainly Afrikaner) families whose founders arrived in the Cape Colony pre-1815 (inter alia Tessenaar, Knoop, Willer, Drotsky, Kube, Meyer, Freislich, Mulder, Jankowitz, Troskie, Schoonraad, Kaltenbach, Kitshoff, Kolesky, Kroll, Latsky, Jewaskiewitz, Masureik, Zowitsky, Beirowsky, Barensche, Valensky). The works also make reference to a long list of emigrants from Poland (inter alia Jerzy Botkiewicz, Michał Kowalski, Jakub Hofland, Ludwik Romeyk, Jerzy Smacke, Hans Bolonje, Tomasz Tyl, Konstanty Kompenski and Mikołaj Barenski) who participated in the initial phase of colonization (up to 1707).

It was nevertheless true that the publications in existence could represent nothing more than a prelude to more insightful research work, hence the goal of the present article to go a step further, by bringing together knowledge obtained in the course of an analysis concerning certain South African and Dutch archival sources and other publications - from South African authors. An attempt has also been made here to reinterpret certain facts or understandings obtained or arrived at earlier.

Many foreign researchers dealing with the history of South Africa fail to discern the Polish origin of some of the emigrants from Poland. This may be wondered at, since the co-participation of Poles in the founding of the Cape Colony is referred to in a variety of different sources. In one of her letters penned from Cape Town between 1797 and 1801, Lady Anna Barnard wrote: "The early settlers, though under Dutch rule, were not wholly Dutch, but were made up also of Flemings, Germans, Poles, and Portuguese, mostly of a low class" (Barnard 1910: 5). Similar observations were made by Sir John Barrow (1801) as he travelled around South Africa in the years 1797-98; and the same viewpoint was also persisted with by 20th century author Simon A. de Villiers (1971). However, while the role played by the Dutch, Germans and French has consistently been presented rather effectively (Höge 1946; Coertzen \& Fensham 1988; Shell 2005), that of the Polish pioneers has tended to remain poorly recognised.

\section{Poles and overseas expeditions}

According to some researchers, a substitute for maritime expansion at the time of Poland's imperial flowering (1569-1648) was provided by eastward expansion on land (Tazbir 2001). However, there were also initiatives seeking to make the Commonwealth a marine power. These gathered pace during the reigns of Wasa-dynasty Kings Zygmunt III and Władysław IV (i.e. between 1587 and 1648). A small Polish fleet of commercial vessels sailing to ports in Western Europe came into existence, while the operations of the battle fleet were very largely confined to the Baltic Sea. Crews were mainly made up of people from the Kashubia region, or else of Zaporozhian Cossacks, who were familiar with service at sea, thanks to their having sailed on vessels in the Black Sea. Reigning between 1674 and 1696, King Jan III Sobieski came back to plans for a more overt Polish maritime presence, and during his reign, the number of vessels forming the Gdańsk commercial fleet rose from 25, to 64 in 1694. Vessels from Gdańsk made it to the furthest corners of the known world. Relatively the greatest number sailed to the East Indies, and the route there led around the southern coast of Africa (Kowalski M.A. 2005).

Attempts to acquire possessions overseas were made by the Dukes from the coastal provinces of the Polish-Lithuanian Commonwealth. Thus the ruler in Courland, Jakub Kettler (1610-1682) established a colony on Tobago called 'New Courland', and maintained it through the period 1654-1690 (if with short breaks). Proving a little less durable (only lasting from 1651 to 1664) was a colonization process taking in the coast of The Gambia. A colonial endeavor was also attempted by Duke of Prussia Frederick Wilhelm Hohenzollern (1620-1688) - in the years 1682-1688, he maintained a fort and factory on the Gold Coast of what is today Ghana, while in 1685 he obtained from the Danes the right to found factories on the Virgin Islands. One hundred years later (in 1780), Karol Radziwiłt set up within his Duchy of Nesvizh the first school that would train personnel for the Polish-Lithuanian Navy (Kowalski M.A. 2005).

The leader of the Brandenburger-Prussian expedition that founded the Gold Coast colony in 1682 was Otto Friedrich von der Groeben (1657-1728), a member of the Prussian nobility with strong Polish associations. He was born in the country's Varmia region, spending time there in childhood and 
attending the Jesuit College in Reszel. His estates were in the Kwidzyn area, and hence within the then Polish-speaking part of Ducal Prussia. His first foreign travel (in 1673) was passed in the company of the Pole Col. Krzysztof Meglin, an emissary of the Polish Court. In 1681, he entered the service of Elector Frederick William of Brandenburg (also Duke of Prussia). He ended this briefly in 1684, and then finally in 1720, when he was appointed a General in the Polish Army (Ratzel 1879; van der Heyden 2001).

\section{Poles in the Dutch colonial empire}

The shortlived nature of domestic initiatives to develop the fleet and acquire overseas possessions ensured that a quite large number of Poles did become committed to foreign colonial undertakings in the 17th and 18th centuries. A known and quite spectacular episode concerned the presence of Poles among the colonists founding the first permanent British settlement in North America ${ }^{1}$. However, much greater numbers played a part in the Dutch colonial ventures of that era.

In more modern times, the Commonwealth of Two Nations and the United Provinces of The Netherlands were linked by rather strong ties in various spheres of activity (Thijssen 2003). The motor force behind the relationship was provided by economic interests, as well as friendly political relations. The two states were included among the free political systems, a fact that again favoured a certain closeness. A rapidly-developing Dutch economy drew in considerable amounts of the necessary raw materials from Poland (not least grain and timber). Holland also had one of the most powerful fleets in Europe at that time, and in line with this conditioning there was a preponderance of Dutch ships among those calling in at Polish or Lithuanian ports. Links were also favoured by cultural similarities, in that the German dialects widespread in coastal regions of the Commonwealth (most especially the Lower Prussian, i.e. the Niederpreußisch) were very similar to Dutch. Polish Protestants also maintained strong ties with Holland, so together these were circumstances that gave rise to certain migratory movements between the two countries. It is a well known fact that Dutch merchants and

1 Jamestown was founded in 1607 in what is today the state of Virginia. The further settlers and soldiers arriving there the following year included several Poles (Pula 2008). artisans settled in Polish cities, first and foremost Gdańsk. Beyond that, many Dutch specialists - including doctors, teachers and surveyors - found employment in the larger mansions. It was (Mennonite) migrants from Holland who commenced with settlement in Poland on the basis of olęderskie rights, and indeed the very word relates to 'Hollander', though in fact that process was also later participated in by Germans and Poles too. Equally, there were movements in the opposite direction. Many Poles took up studies in Dutch higher education, also seeking work there or better life chances. Beyond that, some were driven by the desire for adventure - or forced by their circumstances - to look for work, or even a permanent place of residence, in the Dutch overseas possessions. They were recruited either in The Netherlands, or even directly in the Commonwealth ports.

The role played by individual Poles in Dutch colonial undertakings to the west is well known. By 1638, Krzysztof Arciszewski (1592-1656) had reached the pinnacle of his career with the Dutch West India Company (Geoctroyeerde Westindische Compagnie; GWIC), holding the position of Commander-in-Chief of the Dutch forces in Brazil. Most likely hailing from Węgorzewo, Albrycht Zaborowski (1638-1711) was from 1662 a pioneer of Dutch settlement in what is today New Jersey. He gave rise to the well-known Zabriski family in the United States. Not long after Zaborowoski (and probably also other Poles) settled, the Dutch Governor asked his superiors in Europe to send more Polish Protestants expelled from their homeland (Haiman 1974).

Seemingly less well-known is the role Poles played in Dutch colonial undertakings in the Southern Hemisphere. Nevertheless, it was the Asian possessions that attracted the greatest attention of the metropolises, and there that the greatest efforts were being made. Analysis of the archival documents of the Dutch East India Company (Vereenigde Oost-Indische Compagnie; VOC) has helped with the identification of several thousand men originating in the Polish lands who boarded ships bound for the Dutch Indies in the 17th and 18th centuries. Many of these stopped off in South Africa on the way. There was a prevalence of the inhabitants of the two Prussias, and first and foremost of those hailing from Gdańsk on the one hand or Königsberg on the other. However, there was also no shortage of people from other regions of Poland and the Commonwealth (not least large 
numbers from Warsaw and Cracow; Nationaal Archief 2012).

The Cape Colony in South Africa was only founded rather late on, did not assume more major economic significance and only ever maintained a relatively limited military presence. Volunteers from Poland, like those from other countries, were first and foremost inclined to serve in $\mathrm{Hol}$ land's Asian colonies (like Ceylon and Indonesia). Some serving there rose high. Walenty August Dunin from Warsaw was recruited to serve with the East India Company in 1788, and assigned the rank of Corporal. A couple of years later he was on Java, in command, and in the rank of Colonel (Dzwonkowski 1985). After completing their service, many won the status of settlers in the Asian colonies. Among those gaining 'settler' status were Godfryd Feligowski (1695), Jakub Bigos (1700), Jan Sas (1758), Jan Grosiński (1777) and Marcin Wiesiński (1778) - all from Gdańsk, as well as Franciszek Komorowski from Podole (1720), Jan Lillie from Cracow (1761), Franciszek Sawicki (1763), Jan Paweł Wilsiński from Welawa (1774) and Jan Jakub Wenskowski from Königsberg (VOC 1795).

The role Poles were playing in the colonial forces of the Dutch East India Company in the 17th century is made clear by the writings of surgeon Nicolas de Graaff, who took up service in the East Indies five times between 1639 and 1683. In memoirs published posthumously (in 1701), that author notes that service in the Company offered shelter to men of such foreign nations as "Polakke, Sweeden, Deenen, Noor-luyde, Jutte, Hamborgers, Bremers, Lubekkers, Dantsikers, Koninxbergers, Hoogduytse, Oosterlingers, Westfaalders, Bergse, Gulikse, Kleefse en voorts alderhande Moffen, Poepe, Knoete en Hannekemaijers en andere groene kassoepers". Not only are Poles (Polakke) listed first here, but they are also augmented by people from the Prussian city-states (Dantsikers and Koninxbergers). Then there is the term kassoepers, which probably makes reference to Kashubia, and may be intended to indicate the least-Germanised inhabitants of Pomerania and Prussia (van Gelder 1997).

Several decades later, two Poles also wrote up recollections from their days with the Company. One was Jerzy Napora (1731-1792), a sailor who served on Company vessels in the years 1752-1756. He was born near Wegorzewo, only to resettle in Gdańsk in later life. The second individual was Anzelm Teodor Dzwonkowski (1764-1850), a Polish nobleman from the Mazowsze region. In the years 1788-1793, he sailed on the Zephyr, calling at the Cape Colony, India and Indonesia. These recollections written up with considerable verve managed to come through the perturbations of history and be published in the second half of the 20th century (Dzwonkowski 1985; van Gelder 2003). They represent live testimony of the role Poles played in Dutch colonial undertakings in the Eastern Hemisphere.

Conditions genuinely reminiscent of overseas colonies were in fact encountered by many inhabitants of the Commonwealth, at the time that uninhabited areas of Ukraine were settled; time served on distant parts of the Steppe; expeditions made to Moscow, Moldavia, Wallachia and Transylvania; and contacts made with the Eastern world on Crimea or in Turkey. Experiences of this kind may have made people more ready to take up service in the Dutch colonial forces. Further factors may have been withdrawal from Polish possessions in the East, the crisis afflicting the Commonwealth's armed forces, and the resultant loss of assets, sources of upkeep and posts. The crisis the Commonwealth as a leading European power experienced combined with a stalling of eastward expansion; and these factors do not go unnoticed by inhabitants in quite distinct parts of the country (not least Prussia). Limitations of the opportunities in the east of the country may indeed have inclined many potential soldiers and settlers to seek their life chances elsewhere, not least in Holland's overseas colonies.

\section{The emergence of the Cape Colony}

The sea route to South East Asia ran along the coast of Africa. The southern tip of that continent, located about half way to India, was not of itself a draw for colonist-Europeans, but it was a natural location for a supply base. In 1652, a Dutch expedition was sent there with the task of founding a post. Shortly thereafter a port and fort took shape, as well as a permanent garrison under Company rule (Figs. $1 \&$ 2). To ensure proper backup facilities for the port and fort, several hundred settlers were brought in from Europe in the years 1652-17072. Later immigrants from Europe did not come in such large numbers, and tended to merge into the society that was taking shape up to the beginning of the 18th century (Żukowski 1994; Leśniewski 2008).

\footnotetext{
${ }^{2}$ A census taken in 1695 revealed 406 men, 186 women and 444 children, as well as 711 crew members.
} 


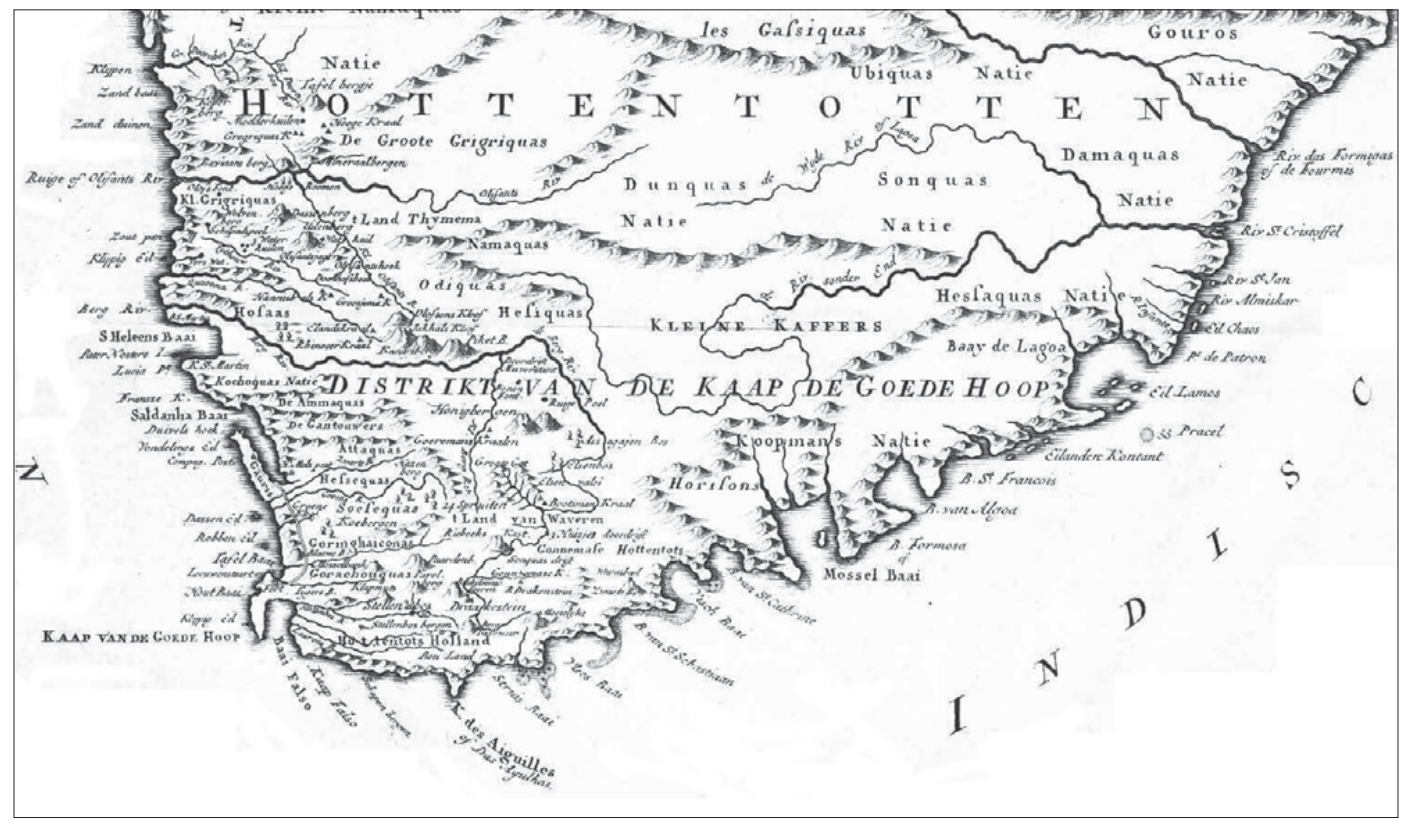

Figure 1. Section of Isaak Tirion's Map of South Africa Kaart van het van Afrika Zuidelykste Gedeelte of het land der Hottentotten, made about 1730.

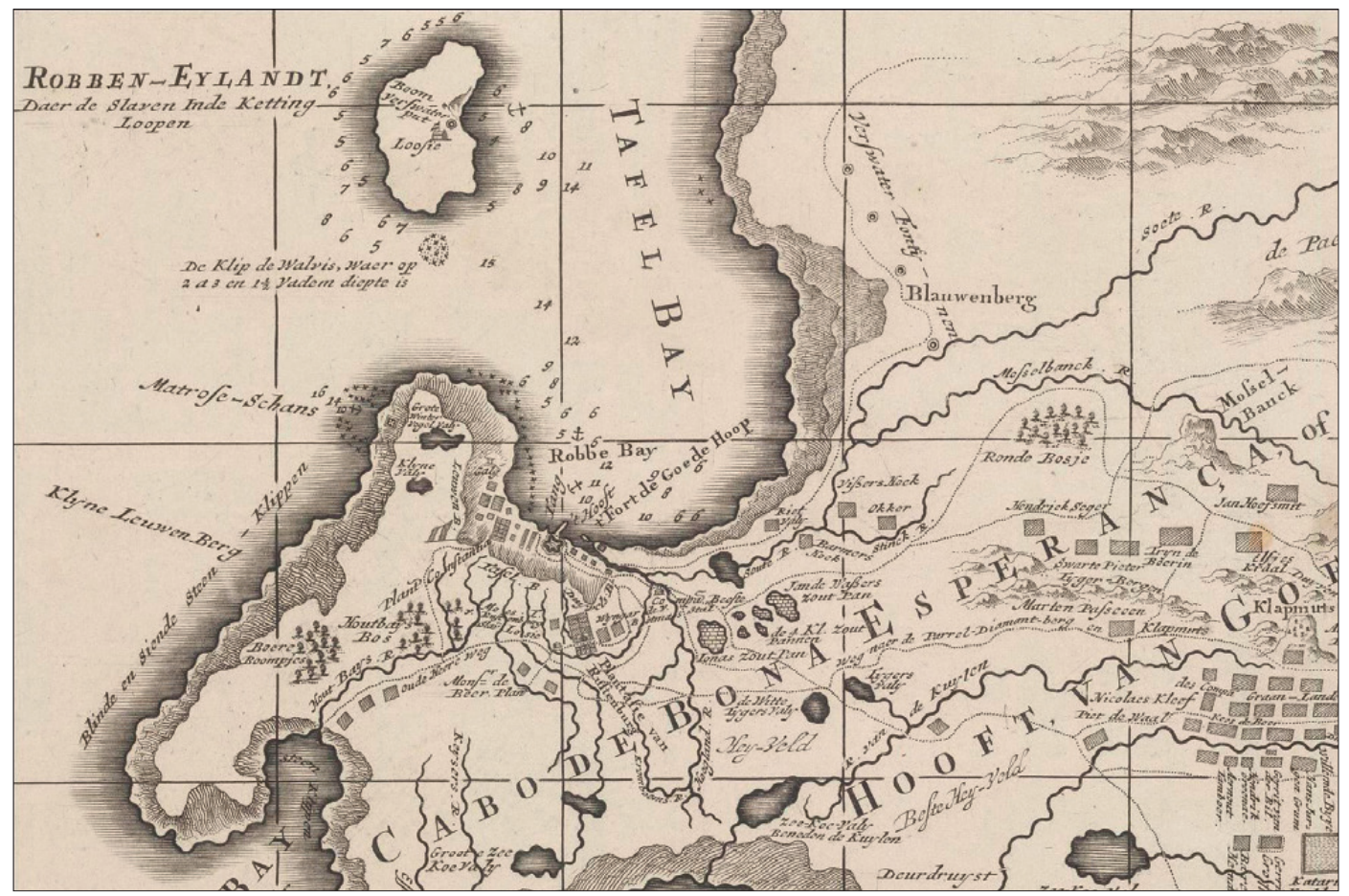

Figure 2. Section of Johannes Loots's Map Naaukeurige Nieuwe Land-en Zee-Kaart, het van der Kaffersche voornaamste Gedeelte Kust, Begrypende de Sardanje-Bay en de CAAP de Bonne Esperanca meth alle des Zelfs Plantazien made about 1700, showing the state of development of the Cape Colony after 50 years of European colonisation. 
In seeking to build the foundations of its rule in South Africa, the Dutch East India Company took on people from various different countries. One indication of this is provided by the established origins of today's Afrikaaners. Calculations by Heese (1971) suggest that $36.8 \%$ of these people's ancestors derived from The Netherlands, 35.7\% from Germany, 14.4\% from France, 2.7\% from the British Isles, 2.9\% from other European countries (Poland included) and 7.5\% from countries outside Europe. In turn, work on the origin of the ancestors of contemporary Afrikaaner Jaco M. Greeff would seem to suggest that Heese exaggerated the role played by immigrants of German origin, at the expense of the French. The largest group of Greeff ancestors - accounting for a 37.5\% share very close to that given by Heese - came from The Netherlands, while Germans and French accounted for similar (respectively 27.4 and 26.4\%) shares. $1.9 \%$ of the ancestors were from the British Isles, while other European countries (mainly Denmark, Norway and Portugal) accounted for $0.8 \%$. The non-European ancestors (mainly from India) accounted for as much as $6.1 \%$ of the total. Family interlinkages between representatives of what was a small group of European-origin settlers at the outset allow it to be presumed that the representatives of other Afrikaner families will show similar shares (Greeff 2007).

\section{The Poles among the Cape Colony pioneers}

A legend known to the Polish diaspora in South Africa holds that it was a man of Polish origin that actually founded the Cape Colony, in the shape of Jan van Riebeeck, whose real name is supposed to have been Jan Rybka ('rybka' means 'a fish' in Polish). However, the factual knowledge possessed as regards the family of this pioneer of Dutch colonisation necessitates complete and unhesitating rejection of this fantastic hypothesis. The only known 'Polish' aspect to van Riebeeck's life is simply the name of his vessel De Coninck van Polen (or 'King of Poland'), on which he set sail in years prior to his expedition to South Africa (Żukowski 1994). However, van Riebeeck's entourage did certainly include a Pole, in the shape of Gdańsk-born Paweł (Paulus) Petkow, who had earlier put in many years service in the Dutch colonies in India. At the time of arrival of the Dutch expedition, he had been a Cadet. However, he quickly won van Riebeeck's confidence, finding himself taking the place of an NCO who had been demoted. It was through this promotion that a place at the table was found for the emigrant from Poland, when the Dutch convened their first ever Council of War in South Africa, on October 10th 1652. The minutes from the three successive meetings after that also carry his signature. The Commandant must have continued to be satisfied with the man from Gdańsk, since the latter was elevated to Sergeant on December 6th 1652 (Leibbrandt 1897a; Höge 1946).

Another outstanding emigrant from Poland, also hailing from Gdańsk, was Jan Liske (Lisky). He came to the Colony four years after it was founded, in 1656. At the outset he was a Cadet's (later a Sergeant's) assistant in the service of the Company, but in 1657 he gained the status of Free Settler (i.e. citizen of the Colony). In 1659, he took part in a 7-man expedition to see the Namaqua tribe, which was living some 20-30 days' journey inland from the Cape of Good Hope. This was very probably the first ever exploratory trip taken into the South African interior (Fig. 4). As of 1660, Liske was helping out on a farm run by the widow of a Dutch settler. However, it seems most likely that the Colony did not meet with his expectations in general, since he returned to Europe that same year (in fact illegally) (Leibbrandt 1897a, 1903; Höge 1946).

During the first two decades of the colonisation process, the fact that the local soldiery included men from Gdańsk-Danzig came to be seen as something normal. Various studies make reference to some 10 of them, though the numbers are also augmented by men from other Prussian cities (Tab. 1 \& 2). We know that one of the men from Gdańsk, Harquebusier Jan Cornelisz, gained free-settler rights in 1662, but no later entries on his subject are to found among the surviving documents. Another - Michał Bischop - was in 1657 serving in the capacity of Junior Surgeon (VOC 1672; Leibbrandt 1897a, 1903; Höge 1946).

The most information from the period in question concerns another inhabitant of Gdańsk called Piotr Mow, who came to the Cape Colony on July 12th 1659, on the Orangie. He started out as a Cadet on 10 guilders a month. Having expected a posting in India, he was reluctant to serve in South Africa, and - as if that were not enough - was also ordered to work in stables. Inevitably, therefore, he sought to escape - on a vessel departing from Cape Town in March 1660. He was detained, how- 
ever, and it was only in the light of the transparently honest testimony he gave that punishment was avoided. The fact that his service up to that time had been exemplary probably also did him some favours. Two months later, he distinguished himself during a reconnaissance, along with five soldiers led by Corporal Elias Giers. The soldiers familiarised themselves with the area around Luipaardberg (today's Tigerberg) Mountain, which is on the far side of Table Bay, this following observations there of an unknown group of Khoikhoi (then referred to as Hottentots). Subsequent service must also have been exemplary because it was Piotr Mow that took on the responsibilities of Giers when the latter died. He was raised to the rank of Corporal himself, on October 25th 1660, his remuneration being 14 guilders a month (Leibbrandt 1897a, 1903; Höge, 1946).

Linkages between the Polish lands - above all Gdańsk - and the Cape Colony are also attested to by the scientific activity of Jakub Breyn (1637-1697), who was an inhabitant of that city. This leading botanist maintained close contacts with the merchants and explorers making trips to South Africa. Thanks to the information - and the seed - with which they were able to supply him, he became the first to cultivate many of the plants characteristic for this extremely biodiverse region (Fig. 3), offering descriptions of them in the 1678 work Exoticarum aliarumque minus cognitarum plantarum centuria prima, which was published in Gdańsk (Kurkowa 1989).

The 1670s saw further soldiers from Poland appear in South Africa. Mikołaj (Cleas) Barenski was from Schiewenhorst (today's Świebno quarter of Gdańsk), but he came to the Cape in 1671 on the Wapen van Zierikzee, again probably as a person less than delighted with his posting. In October of that year, he bid farewell to a colleague and left the fort at the Cape on his own account, being regarded as 'lost' after a couple of days. The suspicion was that he had headed inland in an act of desperation, but he clearly returned to his unit after some time, being dispatched to the Dutch garrison in Ceylon in March 1673 (Leibbrandt 1902; Nationaal Archief 2012). In contrast, a genuinely tragic fate did indeed bring the curtain down on the colonial adventures of one Jan Demant, again of Gdańsk. Ironically, he may in fact have been the very colleague of Barenski already referred to, since the ship taking the former to the Colony (the Tidor) left Holland in the company of the aforemen- tioned Wapen van Zierikzee. On December 30th 1671, less three months after Barenski had made his disappearance, Demant was strangled in the course of a drunken brawl at an inn. The killer was most likely one of the soldiers present there. The same convoy that carried Barenski and Demant included the Ternate, on which Krzysztof Serriers of Gdańsk arrived at the Cape. Like Michał Bischop, he was employed in the local hospital as a Junior Surgeon (VOC 1676-1677; Leibbrandt 1902; HING 2012; Nationaal Archief 2012).

In the 1670s, an important position in the service hierarchy was taken by Albert Bernewitz, of Grobin in Courland. He came to the colony in April 1673 aboard the Asia. A year later, as a corporal, he took command of the strategic outpost on Robben Island. This guarded the entrance to Table Bay, and to Cape Town situated on it (Fig. 2). This was not a well-manned post at that time, the commander being accompanied by just two soldiers.

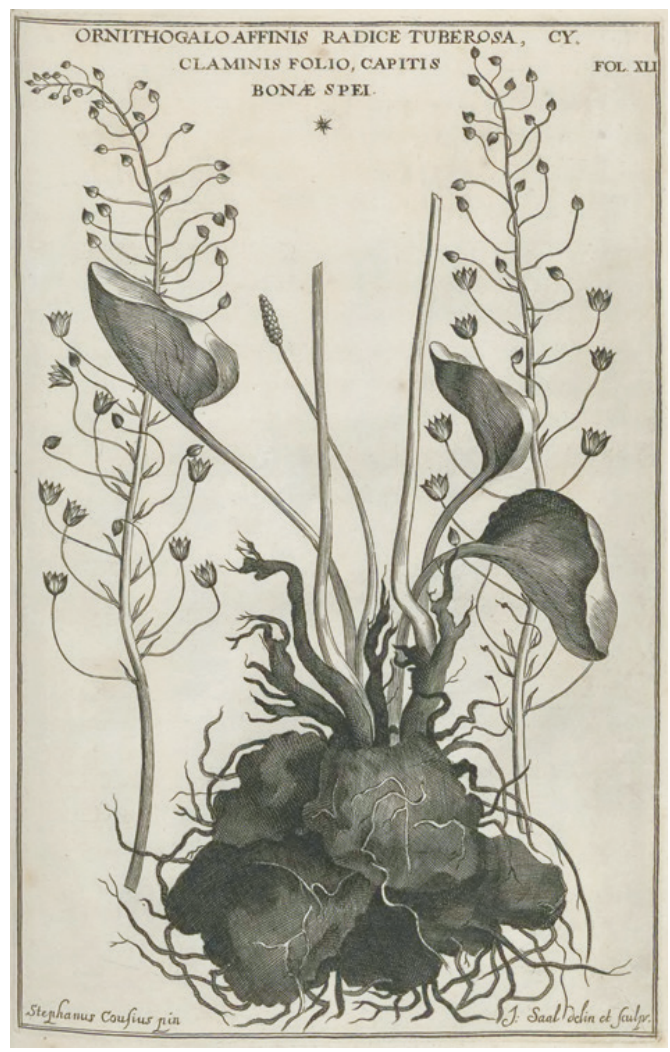

Figure 3. Illustration from the 1678 work by J. Breyne entitled Exoticarum aliarumque minus cognitarum plantarum centuria prima, showing Ornithogalum growing in South Africa. 
In 1679, Bernewitz returned to Europe, but by November 1680 (now with the rank of Sergeant), he was drawn back to serve with the East India Company. Alas, his further fate is unknown (VOC 1676-1677; Sleigh 2004; Nationaal Archief 2012).

The presence of Poles in South Africa may be attested to by the names inhabitants there used. For 1698 , it is possible to note a transaction involving the sale of a 34-year-old slave called Polak (Shell 1986). A hundred years later, another slave went by the name of Danzig, i.e. Gdańsk (Orphan Chamber 1804). The conferment of such names on slaves may perhaps be considered a sign of not-especially-positive attitudes towards Poles on the part of some colonists. These may in fact be behind some of the troubles that befell Mow, Barenski and Dement. Confirmation of this hypothesis may be offered by the term Poolsche Bok, which means 'Polish rack', and was used in the Cape to describe the object to which slaves were bound to be whipped (Ross 1983). A problem involving a negative attitude towards soldiers from Poland had certainly taken shape by the end of the 18th century. T.A. Dzwonkowski recalls in his memoirs how, in seeking recruitment to the Company in 1788, he deliberately concealed his true name and origin. He was afraid of bullying on the part of the German soldiers who were the dominant element in the Company's armed forces. It was pointed out that Poles were characterised by "over- -flamboyance of Polish dress, indecency as regards head-shaving, fanaticism, superstition and tyranny in servitude" (Dzwonkowski 1985).

\section{Jerzy Botkiewicz - probably the first permanent settler from Poland}

On July 10th 1676, Jerzy Botkiewicz from Warsaw arrived in the Colony, following a fourth-month journey on the Wapen van Zierikzee. It was as a Cadet that he commenced a service (Nationaal Archief 2012), whose completion in 1692 was followed by a decision to stay on in the Colony, of which he became a Free Settler (Court of Justice 1694; VOC 1725). His declared sources of upkeep included hunting and the working of salt deposits, and in January 1707 he obtained a concession for this kind of activity close to the Graauw heights. After several months, this was extended to include the Piketberg Mountains area (CAD 1707a, b). He was pioneer explorer of the this area, which did indeed begin to come under management at the beginning of the 18th century (Fig. 4).

Botkiewicz had a homestead on the north-easternmost margins of the area that had been brought under the control of Europeans. This situation of course left him vulnerable. In early September 1707, he was set upon by two slaves on

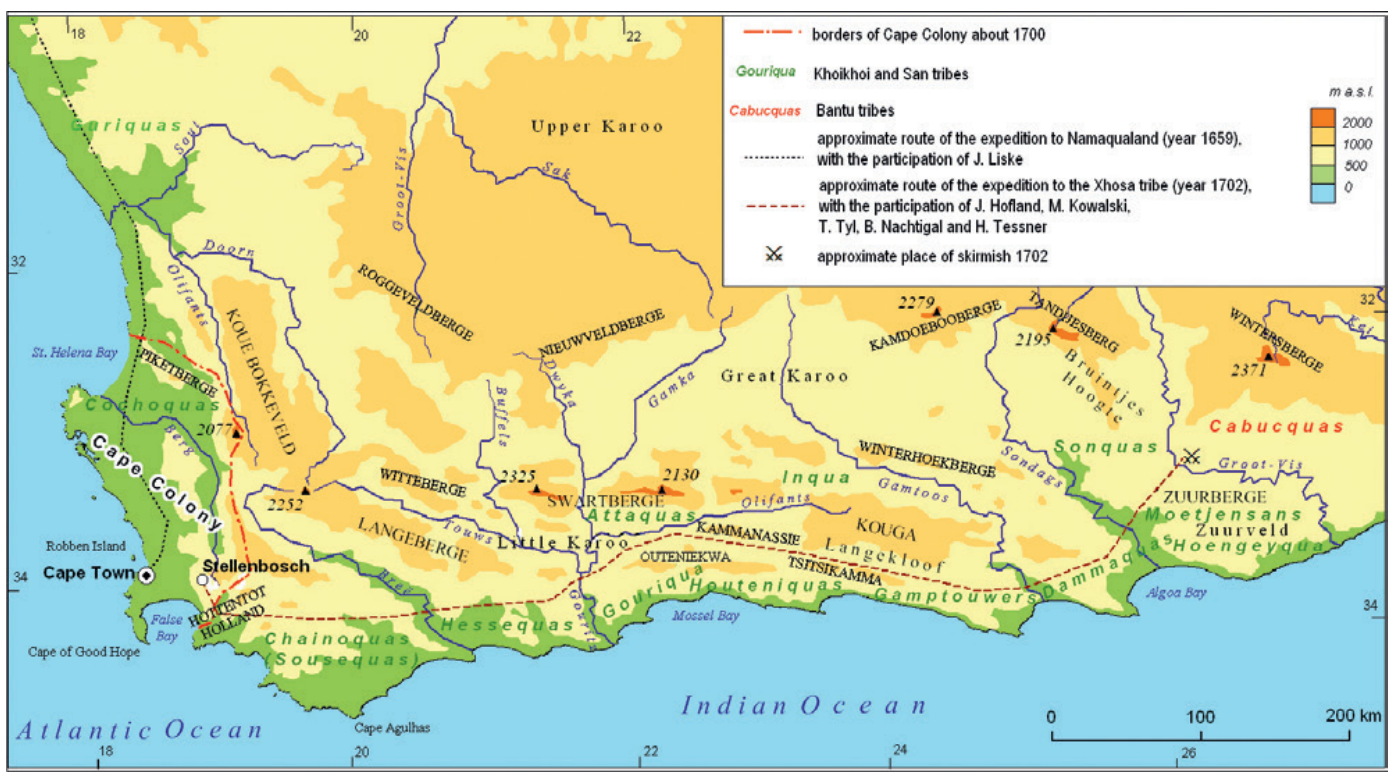

Figure 4. Routes of expeditions on which Poles participated. 
the run: Cesar of Macassar (Indonesia) and Aaron of Bengal. The pair were intent on stocking up with equipment and supplies needed to survive further inland, and when Botkiewicz tried to resist them, he received many a blow from a knobkerrie ${ }^{3}$ that knocked him to the ground. Leaving him for dead, the fugitives plundered the house and then set off. Unfortunately for them, they were soon apprehended and ultimately sentenced to death in court, the entire legal process being experienced by Botkiewicz, who of course testified against them (Court of Justice 1707a,b; Leibbrandt 1896).

In any case, Botkiewicz's activities were not to bring him any real wealth. As of 1720 , his worldly goods essentially consisted of a horse, a sabre, a carbine and a pistol. He had no cattle and did not cultivate his land, while the documents known to the author have nothing to say about any family (VOC 1719b).

The last document known to the author which makes reference to Botkiewicz is the list of employees, dating from 1725 (VOC 1725). It is reasonable to assume that he died shortly thereafter, never again leaving the Colony. He spent about 50 years on the African continent, and hence the greater part of his life.

\section{Settlers from the Commonwealth in the era of the van der Stel Governors (1679-1707)}

The Colony authorities stepped up the settlement campaign in the 1680s and 1690 s, as well as at the beginning of the 18th century (up until 1707). A large group of French Protestants (around 70 families) were shipped in in 1688 (Coertzen \& Fensham 1988), and there was no shortage of settlers or soldiers from Poland. Alongside the still numerous representatives of the two parts of Prussia, there also appeared a quite large group of people from other parts of the Commonwealth. This may have been connected with the Colony governorship being held by the van der Stel family - first Simon, and then his son Willem Adriaan. Simon's second son, Henrik (1670-1722), who also spent a number of years in the Cape Colony (between 1679 and 1686), married Constantia Abrahamsz, a Polish lady from Gdańsk. The newlyweds spent a year (between 1703 and

\footnotetext{
${ }^{3}$ A type of wooden stick terminating in a ball shape that was used by African peoples for both fighting and hunting.
}

1704) at the Cape, en route for the Dutch Indies, where Henrik was to take up managing a Company agency in Macassar (van Epen 1898; Stapel 1933; Böeseken 1964). Their only daughter, Catherina Constantia van der Stel married Henrik Holstyn, also associated with the East India Company. After the death of her first husband, Constantia Abrahamsz married Charles Dierkoop, the Captain of a vessel in Company service. She died a widow in Batavia (today's Jakarta) in 1757 (Notarissen Utrecht 1748; Hoffman 1952; Böeseken 1964).

Generally, the increase in the numbers of Poles appearing in the Cape Colony may also have been associated with the enlivenment of the Commonwealth's maritime policy under King Jan III Sobieski (Kowalski MA 2005).

From among the folk incoming in the 1680 s and 1690s, archival sources do note the presence of several emigrants from the Polish lands who attained 'Settler' status (Tab. 1). These hailed first and foremost from Gdańsk or Königsberg. Some were initially soldiers in the service of the Company, others assigned 'Settler' status from the outset. In the same period (in 1694), Settler rights were conferred upon the aforementioned Jerzy Botkiewicz. Aside from them, several other colonists from the first decades of European settlement may have originated in Poland. Perhaps one of their number was Henrik Fenter (Venter), the founder of what is today one of the largest Afrikaner families. The known documents show that he came to the Colony around 1688, and was from the locality of Hamel (in Western Flanders). However, family stories suggest that Henrik Fenter was from Poland - a claim that the latest genetic studies uphold (Venter 2009).

Similarly shrouded in mystery is the question of the origin of another Afrikaner line, i.e. that of Joost Strydom (Stredon). He came to the Colony at the same time as Venter, Mecklemburg and Grunwald. Genealogists studying this family also do not preclude Polish origin (Kowalski 2006a). Indeed, a hypothesis of this kind gains support from the fact that the Godfather of one of Strydom's sons was emigrant from Gdańsk Marcin Mecklemburg. The names Strydom or Stredon may represent Germanised (or Latinised) forms of Polish surnames like Str(z)oda and Str(z)edowski (German, 1990). There were many more names with a Polish-sounding ring to them (e.g. Koevaal, Fenske, Karpig, Baieck and Wynoch). Equally, it needs to be recalled how known incomers from Poland 
very often had foreign-sounding names, while the origins of a great part of the first settlers have yet to be established.

It has been hypothesised that South Africa offered shelter to one group of 'Polish Brethren' (Żukowski 1994). The 1658 expulsion of these Protestant 'Socinians' (akin to Unitarians) from the Commonwealth (on suspicion of their having collaborated with the invading Swedes) did indeed take place shortly before the Dutch colonization of South Africa. Members of the group are known to have settled in the Duchy of Prussia, The Netherlands, Silesia, Transylvania and the German Lands. Around 1671, Zbigniew Morsztyn - who led the Polish Brethren in Ducal Prussia - did indeed consider the possibility of decamping with his persecuted fellow-adherents to one or other of the Dutch possessions in the East. In the face of the legalisation of the Polish Brethren's presence in the Duchy of Prussia, the idea of emigration overseas was given up on (Pelc 1973, 1977). However, it remains possible that some settlers in South Africa originating in The Netherlands (like Fenter and Stredon), Germany, Silesia or Ducal Prussia (like Kowalski and Romejk), or indeed the lands within the Commonwealth, were of this particular religious background.

Independently of the Colony's settlers, further soldiers hailing from Poland also arrived there. Many (including Hamerling, Bolenski, Smacke, Romejk, Kowalski, Hofland, Wagner, Zablewski and Zaborowski) spent from several up to ten and more years here. As before, there was a prevalence of Prussians, mainly individuals from Gdańsk or Königsberg (Tab. 1 \& Appendix 1; Leibbrandt 1897b; Höge 1946; Nationaal Archief 2012).

Many soldiers were hired for farm work, ensuring them of an opportunity to integrate into white society locally. There were also times that they found themselves (perhaps not in fact by chance) on the farms run by settlers originating within the Polish-Lithuanian Commonwealth. Jan Tollenar was hired out to Marcin Mecklemburg, while Michał Kowalski found employment with Jan Knuppel. After a certain amount of time had passed, some (Kowalski, Romejk, Kleinveld and Eysman) also attained 'Settler' status (Leibbrandt 1897b; Höge 1946; Tab. 1).

In this period, emigrants from Poland-Lithuania were also playing their part in bringing under management certain new areas to the east and north of Cape Town, not least at the emerging town of Stellenbosch (Figs. 2 \& 4). Some came into possession
Table 1. Persons from Poland given the status of Free Settlers (burghers) in the Cape Colony in the years 1652-1707.

\begin{tabular}{|l|c|c|}
\hline \multicolumn{1}{|c|}{ Name* } & Date of arrival & Origin \\
\hline Jan Liske & 1656 & Gdańsk \\
Jan Cornelisz & 1662 & Gdańsk \\
Jerzy Botkiewicz & 1676 & Warsaw \\
Andrzej Quertvoet & 1680 & Königsberg \\
Michał Mester & 1680 & Hel \\
Jan Andresen de Jonker & 1684 & Königsberg \\
Wawrzyniec Campher & 1686 & Gdańsk \\
Krzysztof Weert & 1686 & Königsberg \\
Bartłomiej Nachtigal & 1687 & Gdańsk \\
Piotr Henderikse & 1687 & Gdańsk \\
Marcin Mecklemburg & 1688 & Gdańsk \\
Krzysztof Grunwald & 1688 & Königsberg \\
Paweł Maron & 1691 & Gdańsk \\
Jan Knuppel & 1692 & Gdańsk \\
Ludwik Romejk & 1693 & Źadzbork \\
Gotfryd Rode & 1693 & Gdańsk \\
Jan Maron & 1694 & Gdańsk \\
Michał Kowalski & 1695 & Königsberg \\
Jan Brouwer & 1695 & Gdańsk \\
Piotr Becker & 1695 & Königsberg \\
August Bitzier & 1695 & Königsberg \\
Andrzej Verreyn & 1696 & Königsberg \\
Michał Klein & 1696 & Königsberg \\
Jakub Hofland & 1697 & Königsberg \\
Piotr Malmer & 1700 & Gdańsk \\
Walenty Kleinveld & 1701 & Königsberg \\
Tomasz Eysman & Königsberg \\
\hline
\end{tabular}

"The Polish versions of Christian names are used.

of farms, while many founded families and raised children. Campher's ${ }^{4}$ farm was named 'De Drie Sprong', while Malmer's was 'Seven Rivieren' and Mecklemburg's 'De Zand Fonteyn' (Fig. 5). Some farmers augmented the main activity with hunting and the search for salt. Particular activity in the latter regard was manifested by Marcin Mecklemburg, who resembled Botkiewicz in exploring the Graauw heights, and above all the Groene Kloof

\footnotetext{
${ }^{4}$ Many genealogists indicate Gdańsk as the place of origin of Wawrzyniec Campher (Scholz 2009), but one document gives the locality of Morrouw (Höge 1946) and another Werenhold (VOC 1719a).

${ }^{5}$ It was later purchased by another emigrant from Prussia, Marcin Melck of Klaipeda (in today's Lithuania). The farm is still in existence and is known as 'Muratie'. It is known for the making of well-known kinds of wine, as well as for the heritage architecture from the 18th century (Simons 2000).
} 
area. Irrespective of status or further fate, these individuals joined emigrants from other countries (mainly Holland, France and Germany) in building the foundations for a new society at the far southern end of the African continent (Robertson 2012).

It was possible for soldiers from Poland serving in the Colony to attain significant positions. Originating in Poznań, Marcin Hamerling came here in 1685 as a Cadet. By 1695, he was a Corporal, taking command (like Albert Bernewitz of Grobin before him) of the strategic posting that was Robben Island. In 1701, Hamerling was made a Sergeant, with 10 soldiers (latterly 16) under him. In early 1707, the new Governor of the Cape Colony, Louis van Assenburg, was greeted by a polite letter from him. Continuing in charge at Robben Island until 1721, there was never a longer-serving individual in that posting, and Hamerling demonstrated repeatedly his commitment to his task, as well as his devotion to duty generally (Leibbrandt 1896; Sleigh 2004; Nationaal Archief 2012).

Piotr Wagner from Gdańsk also spent a long period at the Cape, at which he probably arrived on board the Waalstroom in 1695, along with a group of soldiers (including Kowalski and Danowski) that hailed from Prussia. In 1705, he was promoted to Corporal, only to be transferred to Asia three years later (Höge 1946; Nationaal Archief 2012). In 1700, hired by farmer Jan Mulder, he made a journey with four other soldiers to visit the Cape and Gonnema tribes in areas adjacent to the Colony. In exchange for tobacco, brandy, beads and other foods they obtained a certain number of cattle from the natives (Leibbrandt 1897b).

Ordinary soldiers also had distinguished service. Jerzy Smacke of Königsberg arrived at the Cape Colony in December 1695 on the Brandenburg, and was taken on as a farm help from 1702 onwards. In 1704, he was responsible for the recapture of a fleeing slave who had hidden out in the Klapmuts area. He remained in the Colony until October 1709, only to die in 1721 while serving in Asia (Höge 1946; Nationaal Archief 2012). In contrast, Ludwik Romejk of Żadzbork (today's Mragowo) served at the Cape from 1693, and ultimately became a permanent resident. He lacked a farm of his own, but was hired by various farmers over a period of many years. He would ultimately (in 1722) go on to sign a permanent contract of employment with one of these, this assuring him of both food and accommodation (Höge 1946). A much more elevated position in society (and in terms of wealth) was ultimately achieved by Walenty Kleenveldm, also of Königsberg. When he came to the Cape in 1700 he was a private in a regiment of Uhlans. Over time, he advanced to Corporal, and obtained the rights of a Colony citizen, this inter alia allowing him to serve as a Councillor and employee at the Matrimonial Office. He himself got married in 1703 , to an emigrant from Sweden. His ultimate fate was not nevertheless to be associated with Africa, as he returned to Europe with wife and children in 1725 (Höge 1946; Nationaal Archief 2012).

Some soldiers were far from enjoying the respect of the Cape authorities, however. One such, known as the Poolssen Edelman ('Polish nobleman') or Poolssen Baron ('Polish Baron'), became a deserter some time after coming to the Colony, opting to take refuge beyond its borders. The 'Wanted' list of February 1696 dubbed him 'a notorious rascal' (seer fameuse schelme). The authorities were prepared to offer bounties of 100 talers, were he to be brought in alive, 50 if dead (Leibbrandt 1887). The Pole in question here may have gone by the name of Paweł Braski - since such a person appears on the list of soldiers hired to help the settlers out in

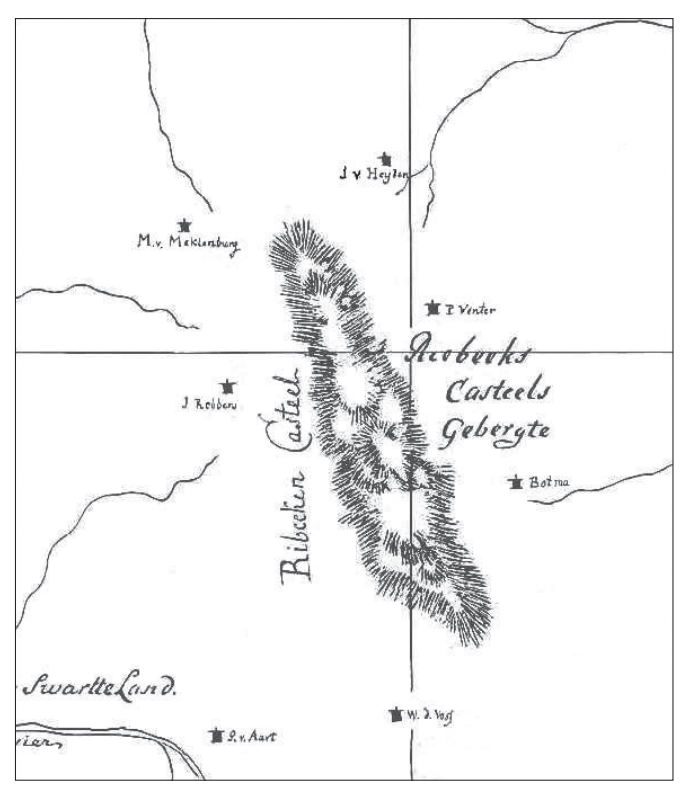

Figure 5. Section of a Map of the Cape Colony made in the early eighteenth century, presenting the area of the Riebeek-Kasteel Mountains (Swartland region), and indicating the farms of settlers (including M. Meklenburg and P. Venter, son of H. Fenter).

Source: Koeman (1952). 
1693 (VOC 1693), as well as on a list of inhabitants of the Colony drawn up in 1695 (Bell 2005). Paweł Braski was then living at the homestead of Abraham Hartog, a Jew originating in Frankfurt-am-Main (VOC 1693; Höge 1946). Hartog was later christened and gave rise to a line of burghers. Braski disappears from such civil documents thereafter, at just the same time as the individual not directly named appears on the aforementioned list of fugitives from the law.

Run-ins with the law might equally characterise settlers who had attained 'Colony Citizen' status. Soldier Bartłomiej (Bartholmeus) Nachtigal from Gdańsk came to the Cape in August 1687 on the Oostsouburg, and was enjoying 'Citizen' status just three years later. However, an attack mounted on Company guards in 1696 resulted in his being sentenced to two years' hard labour, as well as whipping and branding. The judgment of the court noted that Nachtigal (by then 40 years old) was an itinerant of no fixed abode, wandering the country with a blunderbuss, powder and lead shot. It was only in 1702 that he settled down in a distant corner of Drakenstein District. This perhaps became possible after the 1702 expedition during which he came into possession of a herd of cattle and flock of sheep. In 1710, he gained employment as a shepherd for a farmer, while in 1714 - very shortly before his death - he entered into a contract with another farmer, who, in return for a flock of 300 sheep, undertook to provide Nachtigal with accommodation and food, as well as a burial after death (Höge 1946; Shell 2005; Nationaal Archief 2012).

Gotfryd Rode, also from Gdańsk, made similar trouble. Initially a soldier, he was additionally taken on as a tailor (1693-1694) and a farm-help (in 1695). He acquired the status of 'Citizen' later on, this obliging him to settle down, find an honest occupation, and participate in the guard that citizens formed, and the gatherings they convened. Since Rode never complied with these obligations, he was among a group of over ten settlers called to account for themselves in October 1701, at the Cape Town Fort. Failure to report would be punished by loss of civil rights and a charge of vagrancy (Leibbrandt 1896; Höge 1946).

It was probably in the same circles that there moved Piotr Becker from Königsberg (born 1673). He came to the Cape in 1695 as a soldier, but was also taken on as farm help. In 1697, he gained the status of 'Colony citizen', founded a family and became a farmer. However, in 1701 he was sentenced to 10 years' transportation to Mauritius for an attack on Jan Botma, an ensign of Dragoons. To avoid that punishment, he fled inland, only returning to his Drakenstein farm in 1710 . He was sentenced to four years hard labour shortly thereafter and to expulsion to Europe for torturing a slave. In 1717, he returned to the Cape, but was captured and given a life sentence to be served on Robben Island, where he died in the 1740s (Höge 1946).

\section{The role played by Poles in the first armed incident involving the Xhosa tribe}

Company sovereignty was at first confined to a very small area around Cape Town, while the South African interior offered a natural refuge for deserters, runaway slaves, those who had 'fallen out with the law', and those who were just looking for greater freedom, like Barenski, Poolssen Edelman, Nachtigal, Becker and Rode. Ordinary inhabitants of the Colony also saw additional opportunities open up before them if they could only manage to take up a life in the interior. The taking up of new chances beyond the Colony's boundaries was only encouraged by the increasing numbers of settlers, the growing up to adulthood of the first African-born generation, the acquisition of further knowledge on the country and the demonstrable advantage technology appeared to give the incomers over the local native tribes. Thus expeditions organised in the early 18th century had as their main aim the 'acquisition' of cattle from the tribes people. This venture engaging a great many emigrants from Europe (Poles included) was in the nature of a fair trade in many cases, but in others it deteriorated into extortion and pillage. A herd 'acquired' could be sold at considerable profit to individual settlers or institutions of the Colony. The authorities were either unaware of the at-times nefarious methods that had been applied, or else they turned a blind eye to them. It was also naturally a valuable side effect of the expeditions-cum-raids that they were doing much to extend the Colony's geographical horizons.

A participant on one such expedition was Michał Kowalski, who had been born in Königsberg in 1673 and was first present at the Cape in April 1695, having arrived on the Waalstroom. It is in fact hard to say if this was the arrival launch- 
ing his service in the Colony, or whether he first sailed on to Asia, before later returning. What we do know for sure is that, in 1701, he was being hired out as a help to Jan Knuppel, a settler whose home town was Gdańsk. The new activity certainly afforded much greater freedom of action. In 1702, Kowalski was - along with Jakub Hofland from Königsberg and Tomasz Tyl from Warsaw, and four other settlers - among the small group of organisers and leaders of the expedition (Shell 2005) that culminated in the first direct encounters between European settlers and representatives of the Bantu tribes (probably in fact the Xhosa people). Alas, that meeting also ended in the first armed incident between the two communities to be noted in the history of South Africa.

The expedition set off around March 23rd 1702. Ninety men took part in it, including 45 Europeans and 45 Khoikhoi ('Hottentots') in their service. There were four wagons and 32 oxen to pull them, as well as 14 horses. Alongside Kowalski, Hofland and Tyl, there were two other immigrants from Poland (Gdańsk) among the participants, i.e. Henryk Tessner and the aforementioned Bartłomiej (Bartholmeus) Nachtigal. Also from Gdańsk, farmer Jan Knuppel supplied one of the four wagons. The high position Kowalski enjoyed was probably a result of his desire to represent his interests. The official purpose to the expedition was to trade with the Khoikhoi.

Having crossed the Hottentots Holland mountains, the party passed through the territory of the Khoikhoi, i.e. the Sousequas, Hessequas, Gmiris, Attaquas, Gamptouwers, Dammaquas and Moetjensans (Cochesous). From the latter tribe, whose leader the colonists dubbed Snel, several guides and a translator were enrolled, with a view to contacts with a Bantu tribe called the Cabucquas being facilitated (Fig. 4). In fact, however, it did not prove possible to reach its territory, because the Africans learned of the trip and deployed against the Europeans a unit of some 500-600 warriors armed with the short spears known as assegais and protected by shields. The encounter between the two groups took place four days' journey away from the tribe's camp, more than $700 \mathrm{~km}$ east of Cape Town (or a month's march), in territory inhabited by a tribe called the Sonquas Caffers (and in fact a San people otherwise known as 'Bushmen'). The warriors attacked the colonists' camp in the early morning, but were nevertheless repelled. An hour and half later a further attack took place, after which the Africans were forced to flee. The skirmishes, followed by a period of pursuit, cost more than 20 Africans their lives, while one was taken into slavery. The colonists lost only one man, though a second member of the expedition died of natural causes.

The victory has to be regarded as a doubtful one - trade with the Cabucquas tribe never got going, but further battle could not be done, since the colonists were too few in number and had too little gunpowder. They therefore opted to back off, collecting the wagons they had left at the camp of the Moetjesans tribe. Nevertheless, they did not return empty-handed. A first attack launched against the Horisons (otherwise the Kannou, again most probably a San people) involved musket fire that forced the inhabitants to flee, the 50 cattle remaining behind being seized by the colonists. After a march of some 14-15 days, they reached the camp of the Inqua tribe (by members of expedition named as Gonocquas or Hequon). These were in fact the most powerful of the then Khoikhoi (Hottentot) tribes (Elphick, 1985), and they thus offered rich pickings for the increasingly-ruthless colonists, who killed many members of the tribe (including women and children) as they successfully purloined over 2,200 head of cattle and 2,500 sheep. However, some negotiations did take place, and some 400 cattle plus 600 sheep were ultimately returned. In return for the rest, the tribe received tobacco, beads and other gifts. After another fourteen days of the return march, the spoils were divided up between the participants of the expedition (Fig. 4).

The expedition of 1702 reached as far as the river that would later become known as the Groot Vis. The official 1689 expedition that preceded it - as led by Isaq Schrijver - terminated around $100 \mathrm{~km}$ less far out - in the area of the upper reaches of the Sondags (Mossop 1931). The Poles and their associated were thus pioneers of the exploration by Europeans of the lands to the east of the then Cape Colony. It would only be in 1736 that a hunting trip led by Hermanus Hubner would go yet further, crossing the River Kei and thereby reaching the area called Pondoland. Hubner retraced those steps in 1752, in the context of an official colonial expedition led by ensign August Frederik Beutler (Theal 1908-1910; Heawood 1912).

On the basis of a knowledge of the ways the tribes encountered were distributed back then, as well as of the routes taken by expeditions both 
earlier and later, it is possible to reconstruct quite accurately the trail followed in 1702 . The participants at that time had to scale several ranges of the Cape Mountains (the Hottentot Hollands, Langeberge, Kammanassie, Kouga, Tsitsikamma, Zuurberge, Winterhoekberge and Swartberge ranges), the Little Karoo basin, the large Langkloof Valley and several rivers flowing into the Indian Ocean (i.e. the Bree, Gouritz, Groot-Gamtoos, Sondags and Groot-Vis). They most probably returned the same way as they had headed out (Fig. 4).

Information about the 1702 expedition reached the Colony's authorities and representatives were far from pleased by this initiative on the part of the colonists, whose activities became the subject of an official inquiry. At one of the hearings convened, Tomasz Tyl admitted to having taken part in three such journeys. However, notwithstanding their negative assessment of the whole affair, the authorities chose not to punish either participants or sponsors of the expeditions. Presumably, so many inhabitants of the Colony were mixed up in the affair that harsher sentencing could have threatened public order.

Michał Kowalski completed his service with the Company in January 1705 (hence he had most likely signed up for 10 years). In 1706, he joined many other earlier emigrants in obtaining the rights of a citizen of the Cape Colony. Nevertheless, his later fate (like those of Hofland and Tyl) remains unknown (Theal 1888; Leibbrandt 1897b; Höge 1946; Burman 1992; Shell 2005; Nationaal Archief 2012).

One major effect of the 1702 expedition was the introduction of a ban on further 'trade' with the local tribes. Unsurprisingly, this was a factor raising tensions between the colonists and the Colony's authorities, ultimately leading to a revolt in 1707 (Shell 2005).

\section{The influence of emigrants from Poland on the local community}

It was the revolt engaged in by inhabitants of the Cape Colony in 1707 - and the associated resignation of Governor Willem van der Stel - that curbed mass European settlement and signalled the symbolic end of the initial phase of European colonisation. The few immigrants from the pre -1707 period came to represent the demographic and cultural foundation of the society that was coming into existence in southern Africa. It is, for example, thanks to this particular circumstance that the aforementioned small founder group of French Huguenots (just 70 families strong) are present in the ancestry of around a quarter of all today's (3,000,000 or so) Afrikaners. The 18th century mainly brought the arrival of individual immigrants - a phenomenon that favoured their rapid assimilation into the society that had already been shaped in the first 50 years of colonisation. The new arrivals also included several tens of people originating in the Commonwealth lands. Among others, the ancestors of the Tessenaar, Kroll, Kube, Drosky, Jankowitz, Troskie and Schoonraad families. (Kowalski 2006a, 2006b, 2009).

In the 1790s there was again some resumption of larger influxes into the Colony of Poles, primarily as soldiers. This trend was maintained until the time of the Colony's formal takeover by Britain in 1814. Decisive roles in generating the emigration in question were naturally played by the partitioning of Poland, the French Revolution and the consequent Napoleonic Wars. These were times during which Poles found themselves incorporated into many different armies, not least those of the Dutch, French and British - all of which might find their way to the Cape Colony. Several tens of individuals decided to settle here permanently. These included the forebears of the Zowietsky, Kitshoff, Kolesky, Latsky, Beirowski, Jewaskowitz and Masuirek families (Kowalski 2009).

The last stage in the process by which the Afrikaaner community was reinforced by settlers from Poland coincided with the Cape Colony's period under direct British control, which extended from 1814 through to 1910 . However, unlike in previous times, the incoming settlers now tended to be in families, and mainly - moreover - in the context of two main settlement 'campaigns' - of 1857-1861 and 1876-1878. The greatest number of Polish participants hailed from the parts of Poland partitioned by Prussia, most especially from the district of Babimost. It is from Babimost (German: Bomst) and the surrounding area that there originate the ancestors of the Ankiewicz, Henfling, Liss, Schukala, Waberski, Weimann and Woicichowsky families. Closely allied with them are representatives of the Baranski and Dobrowski families. Other parts of Poland - mainly its Prussian-partitioned part - were the source of the Dombrowski, Juritz, Gregorowski, Bogocki-Aproskie, Lazarus, Skow- 
ronek, Skorbinski, Witkowski, Jacobi-Grabowski, Prozesky, Pachonick, Neizel, Dubiel, Lietkie, Robek, Stark, Lepinski, Mantej, Czapiewski, Zalewski and Rewitzki families, among others. (SAG 1986-2008; Schmidt 1955; Schwar \& Pape 1958; Pama 1983; Ankiewicz 1992; Raniowski 2005).

Poles were never such a large group in the Cape Colony as the Dutch, French or Germans. Nevertheless, people of this origin were by no means insignificant, bearing in mind the overall small size of that early society. If there were just a few hundred permanent settlers in the initial (pre-1707) period, then among those some 20-30 incomers were from Poland-Lithuania (Tab. 1). As of 1814, this number had risen to around 100 (Höge 1946; Kowalski M 2006a, 2009) - by this time among just several thousand immigrants that had settled in the Colony. Hence even a general estimate may support the contention that around $1 \%$ of the ancestry of today's Afrikaners is Polish. The presence of compatriots in the forces stationed in the Colony raised their importance. More than once, Poles did many years of service, participating in full in the life of the local community.

It is possible to note an above-average, disproportionate presence of Poles in certain domains. They took part in important events and served in positions of responsibility. They were inter alia included among the groups pioneering expansion inland into Africa. This role played by emigrants from Poland was first and foremost acknowledged by R. Shell, who opined that: "all we may conclude is that it was the Cowalskys of this world, rather than the Van der Merwes who opened up the frontier in this early period". However, while the surname chosen (properly Kowalski) is the one most typically used to denote Poles, being the equivalent of the English 'Smith', Shell unfortunately fails to recognize this origin, considering his 'Cowalskys' to be of Teutonic origin (Shell 2005). A similar oversight was committed by de Wet (1981), who only perceived one Pole among the 1613 studied settlers in the Colony between 1657 and 1707. Similarly, Höge (1946) elected to regard all emigrants from Prussia as 'Germans'.

In fact, notwithstanding the cultural distinctiveness of Prussians and the inhabitants of other lands within the old Commonwealth of the Two Nations, Prussian settlers of the Cape Colony made no bones about their affiliation with the earlier homeland. It was from Prussia (Gdańsk) that there, for example, hailed the aforementioned
Konstancja Abrahamsz (died 1757), wife of Henrik van der Stel. In her new circles she was recognised as a Pole (van Epen 1898; Stapel 1933; Böeseken 1964). A conviction of this kind was, for example, displayed by Polish nobleman Teodor Anzelm Dzwonkowski, who served as a non-commissioned officer on the Dutch vessel Zephir between 1788 and 1793. During this period, he was twice present at the Cape Colony (between the May and October of 1789 and between August 1792 and March 1793; Cunningham 1975; Dzwonkowski 1985). The settlers whose families originated in Prussia and Gdańsk certainly regarded him as a fellow countryman and boasted of having trust-based friendships with him. A knowledge of Cape society was obtained in this way, and interesting information gathered. Indeed, local relations and climate proved so much to his taste that he sought to follow in his ancestors' footsteps by seeking the right to settle in the Colony. However, at that time, such a privilege as 'Settler' status could only be gained by a soldier of many years' service with the Company. The nobleman's efforts were thus condemned to failure (Dzwonkowski 1985).

The 19th and 20th centuries saw the Polish contribution to the settlement and development of South Africa almost entirely forgotten. This situation might largely be associated with the decline in the political significance of Poland. Prevailing economically, politically and culturally, the German state was successful, not only in physically annexing lands that were historically Polish (like Prussia and the Poznań region), but also in stifling and even partially erasing their Polish character. Being strongly pro-German in any case, and noting the strength that Germany was gaining, the Boers and later Afrikaner tellers of history (and even the researchers into genealogy) had little motivation to untangle the traditions of the Prussias once coming within the Commonwealth of the Two Nations from the Prussias later subjected to a clear process of Germanisation post 1815. This even applied to those whose surnames attested more or less directly to a Polish origin.

This interpretation was still further favoured by the fact that some $25 \%$ of the Afrikaners' ancestors overall were German, while pretty much every family had at least some German blood back there somewhere (this being deemed significant qualitatively, even if the quantitative impact was minor). Such was the pressure here that all came to be regarded as German, irrespective of their time of arrival, or the geopolitical reality applying at that time. 
Even the numerous similarities between the societies did not encourage a more durable remembrance of the role Poles had played in the shaping of the new community in South Africa. Up to the end of the 18th century, both societies (Poles and Boers) were expanding eastwards, each being convinced of its role as a bulwark - and a vanguard - of Christian civilisation. There was an attendant affection for freedom and the rights of the citizen that was as clear in a Polish-Lithuanian Commonwealth lacking more obvious physical boundaries as it was in the Cape Colony, with its vast hinterland. Furthermore, from the late 18th century onwards, Poles and Boers alike were committed to the fight against external forces seeking to bring them under control. In the case of Poland it was the Partitioners (above all Russian) that were involved; in the case of the Boers it was the British and their mighty Empire. In the case of both societies, the 19th century would come to be characterised by alternate states of semi-enslavement and semi-independence.

These similarities were more than superficial, since they arose out of an adherence to the citizen tradition common to both nations, which stood out in modern-day Holland and Poland, as refuges seeking to resist the development of absolute monarchy across Europe. The Dutch institutions and settlers from The Netherlands carried these traditions down to the Cape Province, while a key role was also played by Huguenots freeing from French absolutism. Poles were also able to play their modest part. Even if they did not contribute to the actual emergence of any particular or more-distinct features of Cape society, their presence did certainly reinforce some of those traits. Furthermore, in line with the disproportionate involvement that history demonstrates, Poles may have been able to exert the strongest influence of all on the frontier culture of those living out on the margins of the settled area - margins that were obviously pushed ever further eastwards and northwards during the 18th century, thanks to the activities of the Trekboers and Bastaards.

\section{Summary}

Emigrants from Poland (or more generally the Polish-Lithuanian Commonwealth) came to the Cape Colony throughout the initial (1652-1707) period of the Dutch colonisation of South Africa. Intensifying as the 17th century came to an end and the 18th century began, this phenomenon may be linked up with a cessation of colonial efforts on the part of the Commonwealth's Baltic Duchies (of Courland and Prussia), as well as with the petering-out of the maritime policy pursued by King Jan III Sobieski, and largely founded around the strength of Gdańsk. It was probably in these circumstances that volunteers from Poland sought employment in Holland's colonial undertakings. Enhanced influxes of emigrants at that time also reflected intensified settlement campaigns on the part of the authorities of the Cape Colony. A further factor favouring the presence of Poles among soldiers and settlers alike may have been the Polish links characterising two successive governors of the Colony, i.e. Simon van der Stel and his son Willem Adriaan van der Stel.

Those observing the life of the Cape Colony in the late 18th and early 19 th centuries were aware of the influence emigrants from Poland had had in shaping Cape society. It is possible that a certain influence on these views was being exerted by the especially large group of soldiers from Poland present - and settling - in the Colony in the years 1790-1815. This does not however change the fact that emigrants from Poland had been a constant presence in South Africa throughout (if only to a comparable extent in the period 1679-1707). It may thus be suggested that anywhere else the new colonisation engaged in by Europeans at that time (still prior to the mass migrations of the 19th and 20th centuries) was as fully participated in by Poles as was the formation of this particular community at the southernmost tip of the African continent.

\section{Editor notes':}

Unless otherwise stated, the sources of tables and figures are the author, on the basis of their own research. 
Appendix 1. Some soldiers and sailors from Poland (the Polish-Lithuanian Commonwealth) who served in the Cape Colony in the years 1652-1710.

\begin{tabular}{|c|c|c|c|}
\hline Name $^{\star}$ & Date of arrival & $\begin{array}{l}\text { Last mention about staying } \\
\text { in Colony }\end{array}$ & Origin \\
\hline Paweł Petkow & 1652 & 1653 & Gdańsk \\
\hline Michał Woutersz & 1654 & no data & Gdańsk \\
\hline Marcin Scholts & 1656 & no data & Gdańsk \\
\hline Michał Bischop & 1657 & no data & Gdańsk \\
\hline Andrzej Swart & 1657 & no data & Elblag \\
\hline Piotr Hansz & 1657 & no data & Gdańsk \\
\hline Piotr Mow & 1659 & 1660 & Gdańsk \\
\hline Samuel Gerritsz ${ }^{\star}$ & 1667 & 1672 & Gdańsk \\
\hline Izaak Smitsz & 1668 & no data & Gdańsk \\
\hline Mikołaj Barenski & 1671 & 1673 & Gdańsk \\
\hline Krzysztof Surriers & 1671 & 1672 & Gdańsk \\
\hline Jan Demant & 1671 & 1671 & Gdańsk \\
\hline Albert Bernewitz & 1673 & 1679 & Grobina \\
\hline Jan Kroes & 1678 & 1679 & Königsberg \\
\hline Marcin Waap & 1678 & 1680 & Königsberg \\
\hline Jerzy Konowski & 1681 & 1681 & Plateliai \\
\hline Jan Staborski & 1682 & 1682 & Bydgoszcz \\
\hline Albert Paulsz & 1682 & 1684 & Gdańsk \\
\hline Piotr Jasiński & 1682 & 1682 & Kamieniec Podolsk \\
\hline Jakub Felke & 1682 & 1684 & Gdańsk \\
\hline Szymon Jansz & 1682 & 1684 & Gdańsk \\
\hline Andrzej Emmeryk & 1683 & 1685 & Königsberg \\
\hline Jan Jerzy Schouberg & 1684 & 1685 & $\mathrm{Hel}$ \\
\hline Krzysztof Koopman & 1684 & 1685 & Königsberg \\
\hline Marcin Hamerling & 1685 & 1721 & Poznań \\
\hline Jan Agewal & 1685 & 1686 & Königsberg \\
\hline Jerzy Albrecht Matzen & 1688 & 1693 & Königsberg \\
\hline Krzysztof Albrecht Frasius & 1689 & 1690 & Königsberg \\
\hline Krystian Melow & 1689 & 1689 & Gdańsk \\
\hline Ernest Krystian Wiesastus & 1690 & 1691 & Gdańsk \\
\hline Krystian Raap & 1690 & 1692 & Königsberg \\
\hline Jan Boeyer & 1690 & 1700 & Gdańsk \\
\hline Jan Prince & 1690 & 1712 & Königsberg \\
\hline Daniel Tous & 1691 & 1706 & Prussia \\
\hline Jakub Ipsen & 1691 & 1701 & Gdańsk \\
\hline Jan Wissendorp & 1693 & no data & Gdańsk \\
\hline Dirk Dick & 1694 & 1695 & Gdańsk \\
\hline Krzysztof Lustyk & 1694 & 1696 & Königsberg \\
\hline Jan Lutjes & 1694 & 1698 & Elblag \\
\hline Jan Mulder & 1694 & no data & Gdańsk \\
\hline Jan Lodewyk & 1694 & 1709 & Königsberg \\
\hline Jan Paal & 1694 & no data & Gdańsk \\
\hline Jan Paulusz & 1695 & no data & Ventspils \\
\hline Jan Ostenryk & 1695 & no data & Gdańsk \\
\hline Jan Karol Roshausen & 1695 & no data & Gdańsk \\
\hline
\end{tabular}




\begin{tabular}{|c|c|c|c|}
\hline Name $^{\star}$ & Date of arrival & $\begin{array}{l}\text { Last mention about staying } \\
\text { in Colony }\end{array}$ & Origin \\
\hline Daniel Symber & 1695 & no data & Gdańsk \\
\hline Jerzy Smacke & 1695 & 1709 & Königsberg \\
\hline Henryk Weiman & 1695 & no data & Königsberg \\
\hline Reinhold Schultz & 1695 & no data & Königsberg \\
\hline Jerzy Altrok & 1695 & 1711 & Königsberg \\
\hline Maciej Danowski & 1695 & no data & Gdańsk \\
\hline Albert Bolenski & 1695 & 1702 & Gdańsk \\
\hline Piotr Wagner & 1695 & 1708 & Gdańsk \\
\hline Andrzej Kuiel & 1695 & 1696 & Königsberg \\
\hline Albert Grunwald & 1695 & 1695 & Gdańsk \\
\hline Krzysztof Mulder & 1695 & 1699 & Gdańsk \\
\hline Marcin Beenen & 1695 & 1705 & Gdańsk \\
\hline Marcin Streik & 1695 & 1705 & Gdańsk \\
\hline Henryk Feman & 1695 & no data & Gdańsk \\
\hline Joachim Martensz & 1695 & 1696 & Gdańsk \\
\hline Marcin Nieman & 1696 & 1700 & Königsberg \\
\hline Joachim Carsteed & 1696 & 1699 & Königsberg \\
\hline Izaak Jansz & 1696 & 1700 & Gdańsk \\
\hline Jan Weysel & 1696 & no data & Königsberg \\
\hline Henryk Tessner & 1696 & 1705 & Gdańsk \\
\hline Daniel Brom & 1697 & 1701 & Różan \\
\hline Stefan Stomma & 1697 & no data & Gdańsk \\
\hline Dawid Karkettel & 1697 & 1699 & Gdańsk \\
\hline Marcin Zabrewski & 1697 & 1704 & Holqad Pruski \\
\hline Krystian Didelof & 1697 & 1707 & Gdańsk \\
\hline Jan Tollenaar & 1699 & 1700 & Gdańsk \\
\hline Tomasz Tyl & 1699 & 1702 & Warsaw \\
\hline Jan Boloni $i^{\star \star}$ & 1699 & 1712 & Cracow \\
\hline Krzysztof Tym & 1699 & 1702 & Elblag \\
\hline Gabriel Schein & 1699 & 1700 & Gdańsk \\
\hline Jan Beernik & 1699 & 1710 & Königsberg \\
\hline Grzegorz Hartwich & 1700 & 1702 & Prussia \\
\hline Krzysztof Schultz & 1700 & 1707 & Königsberg \\
\hline Salomon Pietersz & 1701 & 1710 & Ventspils \\
\hline Jan Mosewicz & 1701 & 1705 & Klaipèda \\
\hline Jakub Jansz & 1701 & 1706 & Gdańsk \\
\hline Reinhold Rinck & 1701 & 1724 & Gdańsk \\
\hline Jakub Winkler & 1701 & 1701 & Hel \\
\hline Krzysztof Wolman & 1702 & 1703 & Königsberg \\
\hline Jan Rux & 1702 & 1702 & Gdańsk \\
\hline Henryk Derkel & 1702 & 1704 & $\mathrm{Hel}$ \\
\hline Daniel Peltzer & 1703 & 1704 & Gdańsk \\
\hline Krystian Sonnenberg & 1703 & 1704 & Gdańsk \\
\hline Jan Krzysztof Hilbrand & 1703 & 1704 & Gdańsk \\
\hline Godfryd Hefte & 1703 & 1703 & Königsberg \\
\hline Jakub Jansen & 1703 & 1706 & Gdańsk \\
\hline Konstanty Kompenski & 1701 & 1703 & Byczyna \\
\hline
\end{tabular}




\begin{tabular}{|c|c|c|c|}
\hline Name $^{\star}$ & Date of arrival & $\begin{array}{l}\text { Last mention about staying } \\
\text { in Colony }\end{array}$ & Origin \\
\hline Antoni Siglenski & 1703 & 1705 & Prussia \\
\hline Daniel Cas & 1703 & 1705 & Gdańsk \\
\hline Szymon Zaborowski & 1704 & 1707 & Prussia \\
\hline Daniel Danielsz & 1704 & 1705 & Gdańsk \\
\hline Jan Monsewicz & 1705 & 1707 & Palanga \\
\hline Jerzy Jakub Petersen & 1705 & 1707 & Gdańsk \\
\hline Efraim Cant & 1705 & 1710 & Gdańsk \\
\hline Jakub Riemer & 1705 & 1710 & Gdańsk \\
\hline Jakub Smit & 1705 & b.d & Gdańsk \\
\hline Jan Wagner & 1705 & 1705 & Gdańsk \\
\hline Paweł Bokanowski & 1705 & 1709 & Königsberg \\
\hline Jan Smit & 1705 & 1710 & Königsberg \\
\hline Michał Warnik & 1705 & no data & Courland \\
\hline Jan Ertel & 1705 & 1712 & Toruń \\
\hline Jakub Domke & 1706 & 1706 & Gdańsk \\
\hline Henryk Stach & 1706 & 1707 & Gdańsk \\
\hline Wilhelm Karelsz & 1706 & 1707 & Gdańsk \\
\hline Marcin Wentrost & 1706 & 1707 & Gdańsk \\
\hline Jakub Steenweis & 1707 & 1708 & Gdańsk \\
\hline Maciej Smit & 1707 & no data & Poland \\
\hline Michał Knie & 1707 & no data & Malbork \\
\hline Jan Teller & 1708 & 1712 & Königsberg \\
\hline Paweł Dodek & 1708 & 1708 & Prussia \\
\hline Krzysztof Michelsz & 1708 & 1709 & Gdańsk \\
\hline Henryk de Mey & 1708 & 1709 & Ventspils \\
\hline Krystian Fisser & 1709 & 1715 & Königsberg \\
\hline Krzysztof Teich & 1710 & 1715 & Gdańsk \\
\hline Just de Vos & 1710 & 1715 & Gdańsk \\
\hline Maciej Dombrowski & 1710 & 1718 & Königsberg \\
\hline Krzysztof Staski & 1710 & 1713 & Prussia \\
\hline
\end{tabular}

* Polish versions of first names have been used. Names of persons certainly staying in the Colony for more than one year marked in italic.

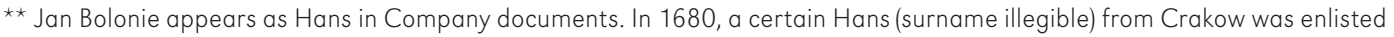
in the Company's service (Nationaal Archief 2012). Perhaps it is the same individual being referred to in both cases.

Source: calculations according to Höge (1946), Nationaal Archief (2012) and several other sources. 


\section{References}

AnkIEWICZ L., 1992. Genealogie Ankiewicz. Familia. Quarterly Journal of the Genealogical Society of South Africa, vol. 29, no. 2, pp. 37-40.

BALL R., 2005. Muster Roll of the free settlers at the Cape of Good Hope for the year 1695. The Genealogical Society of South Africa, Internet: http:// www.eggsa.org/transcriptions/monsterrollen/1695/ mr_1695_intro.htm [21 October 2011].

Barnard A., 1910. South Africa a century Ago. Letters written from the Cape of Good Hope (1797-1801). London: Smith, Elder \& Co., 316 pp.

BARROW J., 1801. An account of travels into the interior of Southern Africa in the years 1797 and 1798. London: A. Strahan, Printers-Street, 419 pp.

BöESEKEN A.J., 1964. Simon van der Stel en sy Kinders. Cape Town: Nasou Beperk, 277 pp.

BREYNE J., 1678. Exoticarum aliarumque minus cognitarum plantarum. Centuria prima, cum figuris aeneis summo studio elaboratis. Gedania [Gdańsk]: D.F. Rhetius, $195 \mathrm{pp}$.

BURMAN J., 1992. The unofficial history of the Cape. Cape Town: Human \& Rousseau, 160 pp.

CAD, 1707a. Receiver of Land Revenue (RLR) 1 (1707). Cape Town: Cape Archives Depot, nr 149, ID 0232.

CAD, 1707b. Receiver of Land Revenue (RLR) 1 (1707). Cape Town: Cape Archives Depot, nr 163, ID 0263.

Coertzen P., Fensham F.C., 1988. The Huguenots of South Africa, 1688-1988. Cape Town: Tafelberg, 189 pp.

Court of Justice, 1694. Court of justice. Cape Town: Cape Town Archives Repository. National Archives of South Africa, no. 2871.1.

Court of Justice, 1707. Court of justice. Cape Town: Cape Town Archives Repository. National Archives of South Africa, no. 782.17.

Cunningham A.M, 1975. Guide to the archives and papers. Johannesburg: University of the Witwatersrand Library, $100 \mathrm{pp}$.

De Villiers S.A., 1971. Robben Island: Out of reach, out of mind: A history of Robben Island. Cape Town: C. Struik, 169 pp.

De Wet G.C., 1981. Die vryliede en vryswartes in die Kaapse nedersetting 1657-1707. Kaapstad: Historiese Publikasie-Vereniging, $246 \mathrm{pp}$.

Dzwonkowskı T.A., 1985. Pamiętniki: czyli pamiq̨tka po ojcu dla Józefy z Dzwonkowskich Komornickiej. Warszawa: Państwowy Instytut Wydawniczy, 125 pp. [elaborated by Stanisław and Tomasz Komornicki from the manuscript].

ELPHICK R., 1985. Khoikhoi and the founding of White South Africa. Johannesburg: Ravan Press, 266 pp.
Friedrich K., 2005. Inne Prusy. Prusy Królewskie i Polska między wolnościq a wolnościami (1569-1772). Poznań Wydawnictwo Poznańskiego Towarzystwa Przyjaciół Nauk, 400 pp.

GeRMan F., 1990. Marcin Strzoda, gliwiczanin, pierwszy polski historyk Ślqska (1587-1649). Rocznik Muzeum w Gliwicach, vol. 3, Gliwice: Muzeum.

Godée Molsbergen E.C. (ed.), 1922. Reizen in Zuid-Afrika in de Hollandse tijd. Deel III. Tochten langs de Z.O.-kust en naar het Oosten 1670-1752. Werken uitgegeven door de Linschoten-Vereeniging, vol. 20, Den Haag: Martinus Nijhoff.

Greeff J.M., 2007. Deconstructing Jaco: Genetic heritage of an Afrikaner. Annals of Human Genetics, vol. 71, no. 5, pp. 674-688.

Halman M., 1974. Polish past in America 1608-1865. Chicago: Polish Museum of America, 178 pp.

HeAwOOd E., 1912. A history of geographical discovery in the seventeenth and eighteenth centuries. Cambridge: Cambridge University Press, 475 pp.

HeESE J.A., 1971. Die Herkoms van die Afrikaner 1657 -1867. Cape Town: A.A. Balkema, 335 pp.

HEESE J.A., 1972. Elandsdrifse besondere begraafplaas. Familia. Quarterly Journal of the Genealogical Society of South Africa, vol. 9, no. 2, p. 58.

Heese J.A. (COmpilation), Lombard R.T.J (ed.), 1986 -2008. South African Genealogies. Stellenbosch: Die Genealogiese Instituut van Suid-Afrika (GISA).

Heyden van der U., 2001. Rote Adler an Afrikas Küste. Die brandenburgisch-preußische Kolonie Großfriedrichsburg in Westafrika. Berlin: Selignow-Verlag, 105 pp.

HING, 2012. The Dutch East India Company's shipping between the Netherlands and Asia 1595-1795. Huygens Instituut voor Nederlandse Geschiedenis, Koninklijk Nederlands Historisch Genootschap, Internet: http://www.historici.nl/Onderzoek/Projecten/DAS/ [21 May 2012].

Hoffman W. J., 1952. Notes on arms of families of Dutch descent. The New England historical and genealogical register, vol. 106, New England Historic Genealogical Society, pp. 4-14.

HöGE J., 1946. Personalia of the Germans at the Cape, 1652-1806. Archives Yearbook for South African History, Pretoria: Archives Yearbook.

Kamieński A., 1995. Stany Prus Ksiq̨żęcych wobec rzqdów brandenburskich $w$ drugiej połowie XVII wieku. Olsztyn: Ośrodek Badań Nauk im. Wojciecha Kętrzyńskiego, 181 pp.

KoEmAn C., 1952. Tabulae geographicae quibus colonia Bonae Spei depingitur. Eighteenth century cartography of Cape Colony. Cape Town-Amsterdam-Pretoria: Hollandsch-Afrikaansche Uitgevers Maatsschappi, $64 \mathrm{pp}$. 
Kowalski M., 2005. Polscy przodkowie Burów. Najwyższy Czas! weekly magazine, no. 7, 12 February, pp. 28-29.

KowALSKI M., 2006a. Polish Boer families. Familia. Quarterly Journal of the Genealogical Society of South Africa, vol. 43, no. 2, pp. 38-46.

KowALSKI M., 2006b. Udział emigrantów z Polski w kształtowaniu społeczności burskiej. [in:] T. Komornicki, Z. Podgórski (eds.), Idee i praktyczny uniwersalizm geografii. Geografia społeczno-ekonomiczna. Dydaktyka, Dokumentacja Geograficzna, no. 33, Warszawa: Instytut Geografii i Przestrzennego Zagospodarowania PAN, pp. 143-147.

KOWALSKI M., 2009. Polish soldier-immigrants to South Africa in the period of French Revolution and the Napoleonic wars (1789-1815). Familia. Quarterly Journal of the Genealogical Society of South Africa, vol. 46, no. 3, pp. 147-164.

KoWALSKI M., 2012. Imigranci z Rzeczpospolitej Obojga Narodów w poczq̨tkowej fazie europejskiego osadnictwa w Kolonii Przyladkowej. Przegląd Geograficzny, vol. 84, iss. 2, pp. 279-312.

Kowalski M.A., 2005. Kolonie Rzeczypospolitej. Warszawa: Dom Wydawniczy Bellona, 368 pp.

KURKOWA A., 1989. Jakub i Jan Filip Breynowie: studium z dziejów kultury książki XVII i XVIII wieku. Wrocław-Warszawa-Kraków-Gdańsk-Łódź: Ossolineum, $153 \mathrm{pp}$.

LeibBRANDT H.C.V., 1887. Rambles through the archives of the colony of the Cape of Good Hope, 1688-1700. Cape Town: J.C. Juta, 222 pp.

LEIBBRANDT H.C.V., 1896. Precis of the archives of the Cape of Good Hope. Vol. 1. Journal, 1699-1732. Cape Town: W.A. Richards \& Sons, Government Printers.

LEIBBRANDT H.C.V., 1897a. Precis of the archives of the Cape of Good Hope. Vol. 5-7. Riebeeck's journal, \&c., Dec. 1651-May 1662, 1-3. Cape Town: W.A. Richards \& Sons, Government Printers.

LeibBRAndT H.C.V., 1897b. Precis of the archives of the Cape of Good Hope. Vol. 4. The defence of Willem Adriaan van der Stel. Cape Town: W.A. Richards \& Sons, Government Printers.

LEIBBRANDT H.C.V., 1902. Precis of the archives of the Cape of Good Hope. Vol. 15. Journal, 1671-1674 \& 1676. Cape Town: W.A. Richards \& Sons, Government Printers.

LeibBRANDT H.C.V., 1903. Precis of the archives of the Cape of Good Hope. Vol. 11-13, Letters despatched from the cape, 1652-1662. Cape Town: W.A. Richards \& Sons, Government Printers.

LeśnIeWski M., 2008. Afrykanie, Burowie, Brytyjczycy: studium wzajemnych relacji 1795-1854. Warszawa: Bel Studio, 565 pp.
Mossop E.E., 1931. Journals of the expeditions of the Honourable ensigns Olof Bergh (1682 and 1683) and Isaq Schrijver (1689). Cape Town: Van Riebeeck Society, 270 pp.

NationaAl ArChief, 2012. Scheepssoldijboeken van de Verenigde Oost-Indische Compagnie. Den Haag: Nationaal Archief, http://vocopvarenden.nationaalarchief.nl/ [21 May 2011].

Notarissen UtreCht, 1748. Procuratie - om gage van Hendrik Holstyn te vorderen by VOC te Enkhuizen. Utrecht: Het Utrechts Archief. Notarissen in de stad Utrecht, Aktenummer, 103, 30 November 1748, 34-4, Inventarisnummer U166a025.

Orphan Chamber, 1804. Inventories of the Orphan Chamber. Cape Town Archives Repository, Cape Town: National Archives of South Africa, nr MOOC8/55.39a.

PAMA C., 1983. Die groot Afrikaanse familienaamboek. Kaapstad: Human \& Rousseau, 380 pp.

PeLC J., 1973. Zbigniew Morsztyn na tle poezji polskiej XVII w. Warszawa: Wiedza Powszechna, 338 pp.

PelC J., 1977. Morsztyn Zbigniew. Polski Słownik Biograficzny, vol. 22, Wrocław-Warszawa-Kraków: Instytut Historii PAN, Ossolineum, pp. 1-5.

PULA J. S., 2008. Jamestown's 400th Anniversary. Polish American Studies, vol. 65, no. 2, pp. 9-15.

RANIOWSKI K., 2005. Rody ziemi wolsztyńsko-babimojskiej. Wolsztyn: Biblioteka Publiczna Miasta i Gminy, $400 \mathrm{pp}$.

Ratzel F., 1879. Gröben, Otto Friedrich von de. Allgemeine Deutsche Biographie, vol. 9, Leipzig: Duncker \& Humblot, 706 pp.

Robertson A., 2012. The First Fifty Years Project. Internet: http://www.e-family.co.za/ffy/index.htm [21 May 2012].

Ross R., 1983. Cape of Torments: Slavery and Resistance in South Africa, London-Boston-Melbourne: Routledge and Kegan Paul, 160 pp.

SCHMIDT W., 1955. Deutsche Wanderung nach Südafrika: im 19. Jahrhundert; Berlin: Dietrich Reimer Verlag, 406 pp.

Scholtz I., 2009. My Familia. Internet: http://myfam. co.za [21 October 2011].

SChWAR J.F., Pape B.E., 1958. Germans in Kaffraria: German Settler's centenary, 1858-1958. King Williams Town: King Print Co., 89 pp.

SHell R.C.-H., 1986. Slavery at the Cape of Good Hope, 1680-1731. New Haven: Yale University [PhD dissertation].

Shell R.C.-H., 2005. The forgotten factor in Cape colonial frontier expansion, 1658-1817. Safundi. The 
Journal of South African and American Comparative Studies, vol. 6, iss. 2, pp. 1-38.

Simons P. B., 2000. Cape Dutch Houses and Other Old Favourites. Random House Struik, Cape Town, $256 \mathrm{pp}$.

SLEIGH D., 2004. Die buiteposte. VOC-buiteposte onder Kaapse bestuur 1652-1795. Pretoria: Protea Boekhuis, 792 pp. [reprint].

Stapel F.W., 1933. Stel, Hendrik van der. [in:] P.C. Molhuysen, P.J. Blok (eds.), Nieuw Nederlandsch biografisch woordenboek. Part 9, Leiden: A.W. Sijthoff.

TAZBIR J., 2001. Sarmaci i świat. Kraków: Towarzystwo Autorów i Wydawców Prac Naukowych "Universitas”, $473 \mathrm{pp}$.

Theal G.M., 1888. History of South Africa 1691-1795. London: S. Sonnenschein \& Co., 419 pp.

THEAL G.M., 1908-1910. History and ethnography of Africa south of the Zambesi. Vol. 1-3. London: S. Sonnenschein \& Co.

THIJSSEN L., 2003. Polska i Niderlandy - 1000 lat kontaktów. Zutphen: Walburg Pers, 302 pp.

van Epen D.G., 1898. De Wapenheraut. Maandblad gewijd aan geschiedenis, geslacht-, wapen-, oudheidkunde enz. Vol. 2, Brussel: Nabu Press, 304 pp.

van Gelder R., 1997. Het Oost-Indisch avontuur. Duitsers in dienst van de voc (1600-1800). Nijmegen: Socialistiese Uitgeverij Nijmegen, 335 pp.

VAN GELDER R., 2003. Naporra's omweg: het leven van een VOC-matroos (1731-1793). Amsterdam: Atlas, $525 \mathrm{pp}$.

Venter P., 2009. Feite, afleidings, aannames en bespiegelinge oor 'n Suid-Afrikaanse stamvader - VENTER. Familia, Quarterly Journal of the Genealogical Society of South Africa, vol. 46, no. 3, pp. 132-146.

VOC, 1672. Resolusies van die Politieke Raad van die Kaap die Goeie Hoop. 11 Aprilis 1672. Verenigde Oostindische Compagnie, 7, Cape Town: Cape Town Archives Repository, pp. 90-103.

VOC, 1676-1677. Resolusies van die Politieke Raad van die Kaap die Goeie Hoop. 28 December 1676 -1 Januarie 1677. Verenigde Oostindische Compagnie, 10, Cape Town: Cape Town Archives Repository, pp. 33-59.
VOC, 1693. Rolle der Vrijhuijden die bij anderen in dienst. 31 December 1693. De archieven van de Verenigde Oostindische Compagnie, Den Haag: Nationaal Archief, nr toegang 1.04.02, inv. nr 4032.

VOC, 1719a. Resolusies van die Politieke Raad van die Kaap die Goeie Hoop. 21 November 1719. Verenigde Oostindische Compagnie, 51, Cape Town: Cape Town Archives Repository, pp. 53-65.

VOC, 1719b. Opgaafrolle 1719 (April 1720). KA 4060. Cape Town Archives Repository. Verenigde Oostindische Compagnie, Cape Town: National Archives of South Africa.

VOC, 1725. Kopie-rol van gekwalificeerde civiele en militaire VOC-dienaren in Kaap de Goede Hoop. 1725 december 31. Verenigde Oostindische Compagnie, Den Haag: Nationaal Archief, nr toegang 1.04.02, inv.nr 12610

White M.D., 2001. Catharina Brits (1797). Familia. Quarterly Journal of the Genealogical Society of South Africa, vol. 38, no. 1, pp. 46-47.

Żukowskı A., 1994a. Kontakty z Afryka Południowa mieszkańców Gdańska w służbie holenderskiej Zjednoczonej Kompanii Wschodnioindyjskiej (II połowa XVII - koniec XVIII wieku). Rocznik Gdański, vol. 54, no. 1, pp. 5-21.

ŻUKOWSKI A., 1994b. W kraju złota i diamentów. Polacy w Południowej Afryce XVI-XX w. Warszawa: Wydawnictwo Naukowe PWN, 311 pp.

ŻUKOWskı A., 2001. Udział Polaków w formacjach wojskowych i porzadkowych w Afryce Południowej na przestrzeni wieków. [in:] A. Judycka, Z. Judycki (eds.), Polacy i osoby polskiego pochodzenia w siłach zbrojnych i policji państw obcych. Historia i współczesność. Materiały VI Międzynarodowego Sympozjum Biografistyki Polonijnej, Toruń: Oficyna Wydawnicza Kucharski, Instytut Badań Biograficznych, pp. 584 $-593$.

ŻUKOWSKI A., 2005. Servicemen from the Kingdom of Poland in the Dutch East India Company and their South African connections. Slavic Almanach. The South African Journal for Slavic, Central and Eastern European Studies, vol. 11, no. 1, pp. 96-106.

ŻUKowskı A., 2008. Diaspora polska w Republice Południowej Afryki w warunkach współczesnej unifikacji i dywersyfikacji świata. Olsztyn: Instytut Nauk Politycznych Uniwersytetu Warmińsko-Mazurskiego, $396 \mathrm{pp}$. 